GENDER STUDIES 19(1)/2020

\title{
sciendo
}

\subsection{8/genst-2021-0001}

\section{SISTERS OF INSPIRATION. \\ FROM SHAKESPEAREAN HEROINE TO PRE-RAPHAELITE MUSE}

\author{
DANA PERCEC \\ West University of Timișoara \\ dana.percec@e-uvt.ro
}

\begin{abstract}
The paper aims to make a connection between the female models of the Pre-Raphaelite Brotherhood and the portrayal of Shakespearean heroines, given that the $19^{\text {th }}$-century school of painting was using the Bard not only as a source of legitimation and authority, but also as a source of displacement, tackling apparently universal and literary subjects that were in fact disturbing for the Victorian sensibilities, such as love and eroticism, neurosis and madness, or suicide. As more recent scholarship has revealed, the women behind the Brotherhood, while posing as passive and contemplative, objects on display for the public gaze, had more agency and mobility than the average Victorian women.
\end{abstract}

Keywords: Pre-Raphaelite brotherhood, female models, Victorian sensibilities, Shakespearean heroines, sisterhood.

\section{Introduction}

The Pre-Raphaelite movement has received a lot of critical attention both in artistic terms and in terms of the literary sources of inspiration this school of painting used. The founders, Dante Gabriel Rossetti, John Everett Millais, and William Holman Hunt were members of the same generation of young imaginative artists, but even half a century after the first PRB exhibition in 1848, a late Pre-Raphaelite like John William Waterhouse had the same technical and aesthetic approach. Escapist and nostalgic, the Pre-Raphaelite painting favours medieval settings, Biblical or mythological themes, lavish costumes and vivid colours. Above all, it brings to the forefront the female subject: beautiful young women in a melancholy pose, enigmatic and inactive, statuesque and aloof. Despite this overall impression, recently published biographies of the real women behind the idealized faces and 


\section{GENDER STUDIES 19(1)/2020}

an exhibition like last year's Pre-Raphaelite Sisters at the National Portrait Gallery in London, curated by the author of a book devoted to these women's contribution to the artistic movement (Marsh, 2016), paint a different picture.

Many of the Pre-Raphaelite models became famous in their time, informal arbiters of a new type of beauty, regarded as strange and exotic by the Victorian standards. Some of them, belonging to modest, working-class backgrounds, got actively involved in the artistic movement, conducted by professional middle-class men, thus showing an upward trajectory that was in fact very hard to achieve by a woman (or by a person, for that matter) in the socially conservative $19^{\text {th }}$ century. Self-taught or educated by the men in their new circles, several of them started to draw or paint, a few exhibiting and being appreciated by influential critics. Others became the lovers or the wives of the Brothers, acting not only as models, but as muses, influencing and changing the substance of the painters' work. Marie Spartali Stillman started by posing for Rossetti and Ford Madox Brown and continued by having one of the longest-lasting and most prolific artistic careers of the entire Brotherhood. Elizabeth Siddal started as a milliner's assistant and continued by being offered a scholarship to study arts by John Ruskin himself. Emma Madox Brown started by being the long-time lover, later wife, of the painter, and continued by choosing the subjects of his compositions for which she sat, imposing her will and point of view. And Muriel Foster was so important for John William Waterhouse that he adapted his subjects, over the decades, so as to suit the age and figure of his model.

\section{Shakespeare's heroines and their Victorian perception}

As Jan Marsh puts it, when the Pre-Raphaelites chose to portray female protagonists in the Bard's plays, they showed them the way the Victorians viewed a medieval lady (2016, p. 10). The relevant part of this argument is the fact that, apart from supporting themselves on the cultural authority of the Bard, the Brothers also approached topics that were of concern for their contemporaries. This was happening in an age when Shakespeare's canonization was already reaching a climax, reflected both in the theatrical performances and in the critical works devoted to him. At the same time, their focus on femininity occurred while the Victorian society transferred its anxieties and expectations about morality onto the women, seen as passive vessels, but, paradoxically, also as active guardians of virtue and stability. All forms of transgression were sanctioned by social practice and by cultural discourses. Therefore, the Pre-Raphaelites' interest in the tragic or problematic fates of early modern 


\section{GENDER STUDIES 19(1)/2020}

female protagonists was a safe way to engage with serious subjects of $19^{\text {th }}$-century Britain, reflecting the clash between a conservative, patriarchal system and the transition towards an age when mentalities about women's autonomy, agency, and conduct were under revision. These "changing, emergent needs of women" (Marsh, 2016, p. 12) were not necessarily emerging per se in the Victorian period, but social reforms and new scientific interests resulted in an altered perception both in the women and about the women.

The Shakespearean narratives about women's relative freedom to love or even to initiate a romantic relationship could raise a few eyebrows in the $19^{\text {th }}$ century, just as a woman's neurotic response to the absence of love, to isolation, to ostracization or shame, to the denial of other liberties could be considered disquieting. From minor and symbolic gestures, such as cross-dressing, putting on men's clothes and temporarily assuming a man's identity, to serious issues, such as the scandalous bed trick or the equally disturbing madness and suicide, the path taken by the Elizabethan women seemed to me more problematic three centuries later, when Puritan and middle-class prudishness ruled. It is true that the Elizabethan transvestite was an acceptable dramatic motif, but was socially disreputable, as indicated by the Hic mulier - Haec vir 1620 pamphlets, which criticized women's masculine fashion in attire and attitude, but lay the blame equally on men's effemination. The bed trick motif has been more ambiguously interpreted, from an "exchange and circulation of bodies" (Eagleton, 1988 , p. 55), where women were mere objects of men's desire, to "a distasteful plot" (Papahagi, 2020, p. 39), an instance of negative, even monstrous agency. As for lunacy, it has always had a two-dimensional, rather simplified quality: it is the result of sin or guilt, whether we refer to the woman's own mistakes or to a man's (though, in the latter case, there was probably something very wrong with the woman, too). Ophelia's madness, as a result of a broken engagement and a broken heart, or the plight of a heroine who, while not Shakespearean, shares a similar fate, the Lady of Shalott, whose broken heart resulted from a broken mirror, are stories to which the Pre-Raphaelites returned again and again.

As pointed out by Angelica Frey (2020), with the development of psychoanalysis, the images of transgressive or romantically tragic femininity became sexually charged to a degree that a proper Victorian would have never dared to admit openly. But in the second half of the $20^{\text {th }}$ century, the women's presence amid the Brotherhood came to be regarded as an example of protofeminism. The same Angelica Frey, discussing the 2019 exhibition, argues that, no matter how revolutionary, free-spirited and non-conformist the group was, they were, after all, a boys' club, treating women as outsiders, objects of art and study, rather than equal partners. Similarly, Lily Katzman and Nadine Daher (2020) contend that, in the women they painted, 


\section{GENDER STUDIES 19(1)/2020}

the Pre-Raphaelites searched the ideal of beauty but also the familiar, in scenes that blended exoticism and details of domesticity. However, most of the models succeeded in negotiating a public image of themselves that denied both the femme fatale stereotype and the angel of the house cliché. Their delicacy and naturalness saved them from the former label, while their unusual dress and poses removed them from the latter.

\section{The story behind the story: fiction and reality}

Shakespeare's heroines proved to be a good platform to showcase the values of this school of painting, combined with a careful and permanent negotiation between the artists and the Victorian public, as well as between the artists' agendas and the personalities of their models. The women's creative involvement in the movement is apparent if their biographies are given more attention. Elizabeth Siddal is by far the best known of all because her face appears on one of the most iconic Pre-Raphaelite paintings and because her short life was one full of passion, suffering, talent, and adventure. Lucinda Hawksley calls her the "art's greatest supermodel" (2020) because of her popularity among artists and the general public in the 1850s. Nowadays, her beauty would be hailed globally, but back in the Victorian period, a tall, red-haired girl was more a source of ridicule than of admiration, thus making Siddal's success even more remarkable. At the opposite end of the spectrum is the mysterious woman in John William Waterhouse's paintings, a model whose identity remained a mystery for a long time. Only a drawing from 1901 includes a helpful caption - "Miss Muriel Foster" - for art critics to be able to identify and write about her (Baker \& Baker, 1999, p. 1). In between the two, there is Fanny Eaton, utterly exotic with her mulatto skin, cast by the Pre-Raphaelites in the most exotic roles, like Zenobia or Sybil (Katzman \& Daher, 2020). She was, doubtless, the very embodiment of the "Other", in a time when the British self-image was that of the civilizer of the world and when a pale, porcelain-like skin was a must for eligible young ladies. Another stunning redhead is Fanny Cornforth, stage name of Sarah Cox, a parlour maid, Siddal's rival for Rossetti's artistic interest and affections. There is also Annie Miller, whose story begins like Cinderella's, the poor girl being "rescued" from the slums by William Holman Hunt and not only elevated to the position of a partner, but also educated so as to become marriageable. Her famous portrait as Helen of Troy (by Dante Gabriel Rossetti, 1863), of a woman who enjoys both good looks and elegance, is illustrative of her spectacular rags-to-riches life and career. And, last but not least, there is Effie Gray, a painter herself, first married to John Ruskin, then to John Everett Millais, after her first marriage's annulment 


\section{GENDER STUDIES 19(1)/2020}

occasioned a true Victorian scandal on the grounds that their union had not been consummated (Frey, 2020). The ménage à trois has been a constant source of inspiration for writers, theatre and film directors (perhaps most famously, the 2014 eponymous movie directed by Emma Thompson and starring Dakota Fanning).

An image to which Victorian artists and poets were drawn was that of female isolation. This reclusiveness worked in two ways. On the one hand, it was seen as a warrant of discretion, decent behaviour, silence, and obedience, exercised by and onto an individual who remained willingly in the private sphere, whose voice was not heard and who followed the requirements to become the coveted angel in the house. On the other hand, as we can notice if we read, for example, Charlotte Perkins Gilman's famous The yellow wallpaper $(1892,2014)$, isolation was synonymous with entrapment. It was a safe way in which the institution of marriage, working inexorably like the institution of the hospital or the asylum, kept the transgressive woman under strict control and surveillance. As Elaine Showalter pointed out in her seminal The female malady from 1987, disorder in women, whether it was physical, mental, or socio-cultural, was "treated" in the same manner, to coerce docility, to curb agency, to impose a normative view on behaviour, gender roles and power relations.

Of Shakespeare's heroines who stirred the Brotherhood's imagination, this paper focuses on Mariana, Angelo's forgotten fiancée in Measure for measure, and Ophelia, Hamlet's tragic bride. The former is significant in her very uniqueness of representation, which makes her all the more conspicuous, whereas the latter's portrait is replicated a record number of times by all the important artists of this school.

\subsection{Mariana}

Heroines who spent time in solitude and isolation, pining away, were among the most attractive in the $19^{\text {th }}$ century. The gallery can begin with Shakespeare's Mariana, the repudiated fiancée in Measure for measure, whose life is described by Duke Vincentio in two brief lines thus: "I will presently to Saint Luke's; there, at the moated grange, resides this dejected Mariana" (Shakespeare, 3.1.266-8). The reasons why she has to live alone and sad in a fortified farm are given more detailed attention: she was abandoned by her lover when her dowry disappeared with the death of her brother. Now her entire activity revolves around mourning for the loss of her brother and her fiancé, of financial stability and marital bliss:

Left her in tears, and dried not one of them with his comfort; [...] in few, bestowed her on her own lamentation, which she yet wears for his sake; (3.1.227-31) 


\section{GENDER STUDIES 19(1)/2020}

This forenamed maid hath yet in her the continuance of her first affection; his unjust unkindness, that in all reason should have quenched her love, hath, like an impediment in the current, made it more violent and unruly. (3.1.240-4)

While the presentation of the abandoned woman seems to follow all the prerequisites of passivity and contemplation, there is a high degree of passion hidden in the woman's very stubbornness not to renounce this state. Paradoxically, she is a dejected maid, but her waiting is endowed with features which are far from the proper, virginal first impression ("more violent and unruly"). When Tennyson (2020a, 2020b) is inspired by Mariana's story to write no fewer than two poems of his own about the maiden in distress and shame, his interpretation, following the strict Victorian rules, is deliberately oblivious of Shakespeare's side commentary. The signs of abandonment, sadness and decay are introduced long before we hear the lady's voice: there is the "blackest moss" in the flower-pots, "rusted nails fell from the knots", and "weeded and worn [is] the ancient thatch", the décor culminating with Mariana's refrain:

She only said, 'My life is dreary,

He cometh not,' she said;

She said, 'I am aweary, aweary,

I would that I were dead! (Tennyson, 2020a)

When John Everett Millais painted Mariana in 1851, he used this stanza for good measure in the exhibition catalogue, but his maiden is more Shakespeare than Tennyson. The devotional setting pays tribute to the Victorian poet, as the woman is facing a stained glass depicting a religious scene - not a random one, but the lily of the Annunciation. This is a bow to Mariana's patroness and the Marian cult in general, but also an indirect meditation on the woman's wasted potential: not being marriageable once she was repudiated, turned into a ruined woman, the only glorious prospect for the weaker sex, marriage and, ultimately, motherhood, is ruined too. Mariana's religiousness is stressed by the altar in the right corner, a candle burning and an icon leaning against the wall. The character is engaged in a proper womanly occupation, useful and decorous, embroidery. She seems to be endlessly alternating two activities, praying and embroidering, a sad, but praise-worthy routine. A mouse is crossing the room, reminiscent of Tennyson's descriptions of poverty and degradation, and distracting the viewer's attention for a moment. Mariana is looking outside the window, in melancholy expectancy, as "he" is not coming and autumn is drawing near, a warning that her clock is ticking and her prime years will be gone soon. Withered leaves from the trees outside 


\section{GENDER STUDIES 19(1)/2020}

are invading the lady's private space, as they have fallen and covered her embroidery (https://www.tate.org.uk/art/artworks/millais-mariana-t07553).

This image was surely supposed to be implicitly compared by the viewers with William Holman Hunt's illustration of Measure for measure, exhibited the previous year, Claudio and Isabella (1850). The novice is dressed in white or light grey, her head fully covered, bathed in the light from a window, behind which there is a tree in full blossom. Isabella, even if she is choosing to devote her life to God in a convent, is an image of spring with her purity, virtue, and grace. Never mind that she is sending her brother to an early grave because, by refusing to be seduced by Angelo, she signs Claudio's sentence to death. Indeed, the brother is standing by her, dressed in black, his hands and legs tied to the wall, brooding (https://www.tate.org.uk/ art/artworks/hunt-claudio-and-isabella-n03447). Isabella is the other version of femininity the play is providing, and Millais duly marks the contrast. His Mariana is dressed in dark colours, not in white, and her solitude has a different cause and meaning than Isabella's desired path in life, with "the votarists of Saint Clare" (Shakespeare, 1.4.5). But Millais offers a subversive message, more in the spirit of Shakespeare's "violent and unruly" Mariana. Dark as the dress may be, it is not mourning black, but a vibrant blue, of fine velvet, with a rich girdle around the waist. More significantly, Mariana is standing up, apparently to stretch after long hours of handwork, but this gesture reveals her womanly shapes which are not - what with the medieval cut of the garment - kept in place by a corset. The curves of her breasts and hips and the languorous pose are what viewers see in the foreground of the composition.

This was not only Millais' way to reconcile Shakespeare, Tennyson, the original Elizabethan plot, and Victorian morality. His model, Effie Gray, was, at that moment, still the unhappy wife of John Ruskin, esteemed art critic and role model but an absurd idealist and prude in private, who had apparently refused to consummate his marriage because he was disgusted by the physicality of a relationship. Effie Gray was already intimate with Millais and would soon become his wife, after the annulment of her first marriage. So, when Ruskin wrote a review of this painting in The Times in May, 1851, saying "I am glad to see that $\mathrm{Mr}$ Millais' lady in blue is heartily tired of her painted window and idolatrous toilet table", he deliberate misinterprets the message of the composition and ignores the model's provocative posture (qtd. in Frey, 2020).

Shakespeare's Mariana is not the only abandoned woman forced to lead a sad and barren life, away from the only acceptable fulfilment, marriage, a plight the Victorians wholeheartedly sympathized with. A character in the Arthurian legends, the Lady of Shalott, a 


\section{GENDER STUDIES 19(1)/2020}

woman cursed to live in a tower and see the world only through a mirror, becomes Tennyson's best known heroine. In the 1832 poem, he introduces this woman as immersed in one domestic activity only, endlessly: "A curse is on her, if she stay/Her weaving, either night or day" (Tennyson 2020c). This has been going on forever, on the island surrounded by walls and roses, a genuine hortus conclusus, in which the proper lady stays, away from all temptations. Her first minor rebellion occurs one night when she watches two lovers "lately wed" and exclaims, wearily: "I am half sick of shadows" (Tennyson 2020c). The misdemeanour gains momentum and is immediately sanctioned when she falls in love with Sir Lancelot at first sight, leaves her loom and rushes out of the tower to meet him. As Jan Marsh (2016, p. 20) comments, the idea that a proper lady might wish to initiate a relationship, or worse, a sexual encounter, to make a proposal, was unacceptable for the Victorians, as it displaced the image of the demure, innocent woman, who could not be proactive lest she should destabilize the gender balance.

It is, therefore, not surprising that the Lady of Shalott was a rich source of inspiration for many Pre-Raphaelites, most famously John William Waterhouse, with his no fewer than three paintings, or William Holman Hunt (c.1888-1905), who presents the lady literally trapped in her circular tapestry, threads unravelling and preventing her from moving, a metaphor of female entrapment in a domestic environment which is oppressive, not liberating or gratifying (https://penelope.uchicago. edu/ grout/ encyclopaedia_romana /Britannia /saxonadvent/hunt.html). Interestingly, Pre-Raphaelite model Elizabeth Siddal also drew a version of the Lady of Shalott, in 1853, sitting at her loom, facing her work and the mirror, an unusually wide window being presented behind her. The scene captures the moment when the woman looks straight out of the window for the first time, the mirror cracks and her weaving is ruined. The look on the heroine's face is suggesting curiosity rather than wistfulness, unlike Waterhouse's lady, who is consumed by agony. Despite her modest attire and hair dress and despite the large crucifix on the window sill, Siddal's lady seems eager to abandon her post and her station in life and pursue a new path, no matter the risks she is taking and of which she is fully aware (https://eportfolios.macaulay.cuny.edu/ arts and culture_ museums andculture/ 2015/ 05/30/the-lady-of-shalott-the-women-behind-the-art/). By way of contrast, Tennyson's lady is entirely lost: "'The curse is come upon me,' cried/ The Lady of Shalott." (Tennyson 2020c) 


\section{GENDER STUDIES 19(1)/2020}

\subsection{Ophelia}

John Everett Millais' Ophelia is an iconic painting, representative of the PreRaphaelite techniques and sources of inspiration. And the story behind it is equally complicated, proving that Elizabeth Siddal was no usual model, but one who accepted the most challenging situations and sat in unusual, taboo-breaking, or uncomfortable conditions. When she was discovered by Walter Howell Deverell, she first posed for him, demurely, as Silvia, in Valentine rescuing Silvia from Proteus (1851), a pose in which the mainstream narrative about femininity fixed the representatives of the weaker sex as being in constant need for protection and guidance from men. The scene from The two gentlemen of Verona shows a kneeling young woman, in conventional costume. Conversely, Deverell's Twelfth night (1850) presents a Lizzie Siddal whose body language contrasts dramatically with her clothes. She occupies a marginal position in the painting, her hands clasped in adoration, sitting by the side of central Orsino, who is engaged in singing the famous opening line of the play, "If music be the food of love, play on;" (Shakespeare, 1.1.1). Technically, neither the cross-dressed Viola, nor the buffoon, Feste, are present on the stage at this moment. Still, Deverell places the two at either side of Orsino, Siddal as Viola and, ironically, Dante Gabriel Rossetti as Feste. No one is paying attention to the clown, though, as the page in the left corner is this red-haired woman, wearing a bright red doublet and white tights (http://lizziesiddal.com/portal/twelfth-night/). As if the medieval looking garments of the models were not unconventional enough, unstructured as they were (Frey, 2020), free of the literal and metaphorical corset, the shorts and tights revealing the best part of a pair of long and slender woman's legs was going completely counter the social custom and fashion of the day.

Posing as Ophelia, Siddal wears the garments that, in Queen Gertrude's description of the girl's drowning, swelled and floated and then dragged her to the bottom of the river, while she was still singing and holding the flowers:

Her clothes spread wide,

And mermaid like awhile they bore her up, [...]

But long it could not be

Till all her garments, heavy with their drink,

Pulled the poor wretch from her melodious lay

To muddy death. (Shakespeare, 4.7.176-184) 


\section{GENDER STUDIES 19(1)/2020}

Her ample, bridal white dress and bouquet, her red hair floating about her head may create an angelic image, but the gaze on the model's face, both agony and ecstasy, must have been confusing for the Victorian viewers. Lizzie's health was fragile even before this adventure, which resulted in severe illness, of which it seems she never managed to be fully rid. After being kept by Millais in a tub for many hours, fully dressed, pneumonia may have degenerated into tuberculosis, for which, in the absence of a true cure, she took the prescribed laudanum. The addiction was inevitable and it affected her health even more seriously, as well as her relationship with Rossetti (Hawksley, 2017). When he was finally persuaded to marry her, Lizzie's illness and substance abuse were advanced enough to cause him great distress, reflected in the numerous portraits he drew of her and the elegiac poems he started to write, like Without her:

\footnotetext{
What of her glass without her? The blank gray

There where the pool is blind of the moon's face.

Her dress without her? The tossed empty space

Of cloud-rack whence the moon has passed away.

Her paths without her? Day's appointed sway

Usurped by desolate night. Her pillowed place

Without her? Tears, ah me! For love's good grace,

And cold forgetfulness of night or day. (Rossetti, 2020)
}

The grief of parting with her, when she died at 32, was a legend with a seed of truth in Victorian London. Losing his ability to both paint and write poetry, Rossetti had Lizzie exhumed to retrieve the collection of poems he had buried in her coffin. In death, she had preserved her beauty, they said, like a gothic heroine (Hawksley, 2017). Rossetti's Beata Beatrix (1870), painted in Lizzie's memory, refers to the other Dante's grief upon losing his muse, Beatrice, whom the Italian poet represented as an angel of Paradise. Lizzie's expression is somewhat similar to Ophelia's, a disturbing combination between pain and suffering, rendered by the paleness of her skin or the greenish and brownish shades surrounding her, and beatitude (https://www.tate. org.uk/art/artworks/rossetti-beata-beatrix-n01279). The painted woman's passion is ambiguous, having potentially a spiritual, transcendental origin, as the title and the descending dove - symbol of the Holy Spirit - suggest, or being drug-induced since the dove is not delivering an olive branch, but a poppy flower, a metonymy for opium and laudanum. Opium is a warning motif in other Pre-Raphaelite paintings, like Waterhouse's Sleep and his half-brother, Death (1874), in which two young men are lying on a bed, possibly in an opium den, given the pipes, the smoke and the painted poppies. The brother 


\section{GENDER STUDIES 19(1)/2020}

closer to the foreground is bathed in light and has rosy cheeks and a serene expression, while the other one is behind him, in the shadows, his face drawn and ashen (https://useum.org/artwork/Sleep-and-his-Half-brother-Death-John-William-Waterhouse-

1874). The line between life and death in the presence of opium, it is suggested, is very thin.

Victorian iconography was very sensitive to female malady, and tuberculosis, the white plague, was so widespread, clinically, that it easily became a literary and artistic motif. As Katherine Byrne (2011, p. 92) argues, the "tubercular aesthetic" was binary: it hailed the innocence, purity and victimization of the young and often beautiful consumptive, suffering of the lung affliction while also dreaming of an unrequited or impossible love; but was also regarded as a "site of social anxiety", expressing the insecurity of the establishment about volatile femininity in general, degeneration, and the marginalization of individuals who didn't fit in the normative frame of health, stability, and good conduct. If tuberculosis was a mainly physical disease, which sometimes acquired social, emotional, or metaphysical connotations, madness worked in the opposite way. Established as hysteria in the medical discourse, it remained, until the $20^{\text {th }}$ century, firmly ensconced in the female gender, its "clinical" manifestations ranging from psychoses, neuroses, and depressions, to behaviour that was regarded as transgressive, which could include even the refusal to follow the preset path (Gilbert \& Gubar, Appignanesi, 2020, p. 12). The madwoman, whether kept "in the attic", as the title of Gilbert and Gubar's famous book suggests, referring to Charlotte Brontë's tragicgrotesque character, or roaming freely and aimlessly in the fields, wearing only a shift, as if recently escaped from an asylum, as the Pre-Raphaelite Arthur Hughes sees his own Ophelia, is a dangerous, "unnatural", disturbing sight for the Victorians' love of order, common sense, and self-control. As Gilbert and Gubar show, the alleged madness was, more often than not, the result of a rift between the resignation and obedience expected of the female subject and the need for more liberties.

It comes as no surprise, then, that both literary texts and visual arts obsess about madness or hysteria, as an expression of "self-division" in the woman's spirit, "a common impulse to struggle free" (Gilbert \& Gubar, Appignanesi, 2020, p. 18). Rossetti's own version of Ophelia, entitled The first madness of Ophelia (1864), can be interpreted in a variety of ways. First of all, it can be argued that it was a confession of guilt, as his relationship with Lizzie Siddal, full of ups and downs, separations and reunions, may have contributed to the deterioration of her health. After all, Shakespeare's Ophelia goes mad after Hamlet rejects her and invites her to take the path of virtue and devotion rather than the "sinful" one of a secular, regular life, as (someone else's) wife and mother. Indeed, the Victorian world was as 


\section{GENDER STUDIES 19(1)/2020}

polarized as the medieval and early modern one, the only alternative for marriage being the church. But here, more than in the case of Mariana, the lady's ineligibility results not only from her repudiation and ruined reputation, but also from her mental instability. Secondly, the bystanders in the composition are more important than Ophelia - in contrast with Millais' painting, focused only on the girl's suffering and subsequent suicide. Horatio, Queen Gertrude and Claudius watch and listen to the girl intently because, one may assume, good and bad behaviour, sanity and madness exist provided they are acknowledged as such by an authority. The former is admired and praised, the latter is studied, altered, disciplined, and regulated. An interpretation of this practice without Foucault's theory (1997) about modern forms of control and punishment would be impossible, but a comparison between the examination performed by Ophelia's watchers and Gilman's story about the confinement of a hysterical woman $(1892,2014)$ is also useful. Claudius' body language, staring intently at the "subject", his chin leaning on his right hand, is the mock professional pose of a doctor surveilling his patient (https://artuk.org/ discover /artworks/the-first-madness-of-ophelia244041). It is not a coincidence that he is the man with the highest rank in the painting, therefore is invested, by social custom, with the right degree of authority to reach a legitimate conclusion about the young woman's current state and subsequent fate. Gilman's protagonist, suffering from severe post-partum depression, is watched with equal professional interest by her husband, who happens also to be a doctor and to know best, ignoring her needs, as well as her symptoms.

Both similar to and different from this rendering of Ophelia's madness is Waterhouse's 1910 portrait. The third in a series of paintings devoted to this popular subject, Ophelia is the most disturbing of all, being the only one to stare directly at the viewer, engaging them unwillingly in her turmoil and dilemma. Her gaze is terrified, as if the prospect of suicide and her imminent drowning were less "mermaid-like" than Queen Gertrude reports in Shakespeare's play (https://arthive.com/ johnwaterhouse/ works/255253 Ophelia). Emotionally grabbing is also the presence of two anonymous female bystanders on a bridge in the background, watching with indifference, even if the victim's distress is so obvious in her body language. Waterhouse may imply that it is equally callous to consider female hysteria an abstract, romantic literary trope and a subject of pseudo-objective medical investigation.

The gallery can end with the above-mentioned Ophelia by Arthur Hughes (1852), a skinny and extremely young girl, the vulnerability of the tragic Elizabethan character being here enhanced both by her age and by her lack of weight (https://artuk. org/discover/artworks/ophelia-205241). Rather than ethereal, like Titania, represented in the 


\section{GENDER STUDIES 19(1)/2020}

woods by Edward Robert Hughes (Midsummer eve, 1908), bathed mysteriously in the delicate light of fire flies, smiling benevolently at the other small fairies who surround her, Ophelia is fragile and ill, possibly suffering from anorexia nervosa, a disorder first diagnosed in 1873, but, like hysteria and tuberculosis, working throughout the $19^{\text {th }}$ century as an archetype of idealized middle-class femininity, as Anna Krugovoy Silver argues (2002). The Victorian woman praised as "the angel" in the house, would be best faithful to her name if her existence of flesh - subversive and disquieting as it was anyway - were to vanish altogether. If Rossetti's Beata Beatrix presents a woman in the moment when life departs her body, eyes closed and mouth open to receive communion, hands clasped around a delicate flower, Hughes' Ophelia shows another version of an unreal, fanciful body - all spirit, no matter while acknowledging, though, the means by which such an aerial state can be achieved in reality - starvation. Additionally, Ophelia's portrayal as child-like is evidence of another residual Victorian mentality, male authors tending to infantilize their female subjects, the result of the woman's perception as an inferior or immature member of the society, in need of control and guidance.

\section{Conclusion}

Some of the Pre-Raphaelite muses have been completely forgotten, while others were rediscovered and refashioned by the "hippie" and popular culture in the latter half of the $20^{\text {th }}$ century. But these women's biographies, personal work or contribution to the movement show a constant dialogue with the social and artistic establishment of the Victorian age, carried out in either a creative, or in a subversive way. If, at a superficial glance, the Brothers' models were mere ornaments, beautiful, yet immobile, admired by many, yet frozen in poses chosen and arranged by the male artists, an embedded reading of their lives and of their engagement with the compositions points in a different direction. In a very conservative period, but in which women were already taking considerable steps towards liberation and inclusion, the Pre-Raphaelite sisterhood offered an example of discreet action, of elegant resistance, of resourceful negotiation. The wide range of meanings and openness to new interpretations that Shakespeare's plays lend themselves to became, for the painters and their models, ideal sites for this negotiation. 


\section{GENDER STUDIES 19(1)/2020}

\section{References}

Anon. (2020). Hic mulier. Haec vir. Retrieved from https://archive.org/stream/hicmulierormanwo00exetuoft/ hicmulierormanwo00exetuoft_djvu.txt [Accessed 2020, December 1] (Originally published 1620).

Baker, J. K. \& Baker, C. L. (1999). Miss Muriel Foster: The John William Waterhouse model. The Journal of Preraphaelite Studies, 8 (Fall 1999), 1.

Byrne, K. (2011). Tuberculosis and the Victorian literary imagination. Cambridge: Cambridge University Press. Eagleton, T. (1988). Rereading literature. William Shakespeare. Oxford: Blackwell.

Frey, A. (2020, November 4). The women of Pre-Raphaelite art. Art \& Object. Retrieved from https://www. artandobject.com/articles/women-pre-raphaelite-art [Accessed 2020, November 30].

Foucault, M. (1997). A supraveghea și a pedepsi. Nașterea inchisorii. B. Ghiu (Trans.). București: Humanitas.

Gilbert, S.M., Gubar, s. \& Appignanesi, L. (Introd.). (2020). The madwoman in the attic. The woman writer and the $19^{\text {th }}$-century literary imagination. New York and London: Yale University Press (third edition).

Gilman, C.P. (2014). Tapetul galben. In Antologie de proză clasică americană (pp. 185-212). G. Stoian (Trans.). București: Nemira (Original work published 1892).

Katzman, L.\& Daher, N. (2020, January 22). The women behind the Pre-Raphaelite Brotherhood. An exhibition at the National Portrait Gallery in London explores 12 women's contributions to the male-dominated artistic circle. Smithsonian Magazine. Retrieved from https://www. smithsonianmag. com/smartnews/revisiting-women-behind-pre-raphaelite-band-brothers-180974035/ [Accessed 2020, November 30].

Krugovoy Silver, A. (2002). Victorian literature and the anorexic body. Cambridge: Cambridge University Press.

Hawksley, L. (2017). Lizzie Siddal. The tragedy of a Pre-Raphaelite supermodel. London: Carlton Publishing, ebook.

Hawksley, L. (2020, July 31). The tragedy of art's greatest supermodel. BBC Culture. Retrieved from https://www.bbc.com/culture/article/20200103-the-tragedy-of-arts-greatest-supermodel [Accessed 2020, November 30].

Marsh, J. (2016). The Pre-Rapaelite sisterhood. Lume Books, ebook.

Papahagi, A. (2020). Providence and grace. Lectures on Shakespeare's problem plays and romances. Cluj: Presa Universitară Clujeană.

Rossetti, D.G. (2020). Without her. Retrieved from https://www.poetryfoundation.org/poems/50284/the-houseof-life-53-without-her [Accessed 2020, July 6] (Original work published c.1862).

Shakespeare, W. (2007a). The comedies. D. Bevington (Ed.). New York, London: Pearson Longman.

Shakespeare, W. (2007b). The tragedies. D. Bevington (Ed.). New York, London: Pearson Longman.

Showalter, E. (1987). The female malady. Women, madness and English culture, 1830-1980. Time Warner Books.

Tennyson, A. (2020a). Mariana. Retrieved from https://www.poetryfoundation.org/poems/45365/mariana [Accessed 2020, November 30] (Original work published 1832).

Tennyson, A. (2020b). Mariana in the South. Retrieved from https://www.poetryfoundation.org/poems/45366/ mariana-in-the-south [Accessed 2020, November 30] (Original work published 1832). 


\section{GENDER STUDIES 19(1)/2020}

Tennyson, A. (2020c). The Lady of Shalott. Retrieved from https://www. poetry foundation.org/poems/45359/ the-lady-of-shalott-1832 [Accessed 2020, December 1] (Original work published 1832).

\section{The corpus (The paintings)}

Deverell, W.H. (1850, 2020). Twelfth night. Retrieved from http://lizziesiddal.com/portal/twelfth-night/ [Accessed 2020, December 1].

Holman Hunt, W. (1850, 2020). Claudio and Isabella. Retrieved from https://www.tate.org.uk/art/artworks/huntclaudio-and-isabella-n03447 [Accessed 2020, November 26].

Holman Hunt, W. (c. 1888-1905, 2020). The Lady of Shalott. Retrieved from https://penelope.uchicago. edu/ grout/ encyclopaedia_romana/Britannia /saxonadvent/hunt.html [Accessed 2020, December 1].

Hughes, A. (1852, 2020). Ophelia. Retrieved from https://artuk. org/discover/artworks/ophelia-205241 [Accessed 2020, December 1].

Millais, J.E. (1851, 2020). Mariana. Retrieved from https:/www.tate.org.uk/ art/artworks/millais-marianat07553 [Accessed 2020, November 26].

Millais, J.E. (1851, 2020). Ophelia. Retrieved from https:/www.tate.org.uk/ art/artworks/millais-ophelian01506 [Accessed 2020, November 30].

Rossetti, D.G. (1870, 2020). Beata Beatrix. Retrieved from https://www.tate. org.uk/art/artworks/rossetti-beatabeatrix-n01279 [Accessed 2020, November 30].

Rossetti, D.G. (1864, 2020). The first madness of Ophelia. Retrieved from https://artuk.org/ discover/ artworks/the-first-madness-of-ophelia-244041 [Accessed 20202, November 30].

Siddal, E. (1853, 2020). The Lady of Shalott. Retrieved from https://eportfolios.macaulay.cuny.edu/ arts and culture_museums andculture/ 2015/ 05/30/the-lady-of-shalott-the-women-behind-the-art/ [Accessed 2020, December 1].

Waterhouse, J.W. (1910, 2020). Ophelia. Retrieved from ttps://arthive.com/ johnwaterhouse/ works/ 255253 $\sim$ Ophelia [Accessed 2020, November 26].

Waterhouse, J.W. (1874, 2020). Sleep and his half-brother, Death. Retrieved from https://useum.org/ artwork/ Sleep-and-his-Half-brother-Death-John-William-Waterhouse-1874 [Accessed 2020, December 1].

Dana PERCEC, PhD, is Professor of English at the West University of Timişoara, Romania. She teaches early modern English literature, British Studies, and literary translation. Her main interests are Renaissance studies, gender studies, and Victorian literature. She is the author and co-author of several books about Shakespeare's plays, early modern England and Victorian Britain, and the editor of a series devoted to literary theory and genre theory. She has published studies and articles on these topics in many journals. She is a member of the Romanian Writers' Union and a columnist for several literary and cultural journals. 